Check for updates

The BMJ

fgodlee@bmi.com Follow Fiona on Twitter @fgodlee

Cite this as: BMJ2021;373:n1472 http://dx.doi.org/10.1136/bmj.n1472 Published: 10 June 2021

\title{
Governments should be made to work harder to keep public trust
}

\section{Fiona Godlee editor in chief}

Trust is at the heart of healthcare-it takes time and care to build but can be lost in a moment. And those who lose the public's trust should have to work hard to regain it.

First, some good news. After widely expressed concern the UK government has pushed back its rushed and poorly communicated plan to extract patients' deidentified data from general practice records (doi:10.1136/bmj.n1325;

doi:10.1136/bmj.n1455; doi:10.1136/bmj.n1451). ${ }^{1-3}$ This will give time to build public trust. But, even so, many patients may choose to opt out, making these crucial data much less useful, writes Angela Coulter (doi:10.1136/bmj.n1413). ${ }^{4}$ Better to insist on more transparency and on involvement of the public in decisions on how data are collected, accessed, and used. As well as these important safeguards, patients should have online access to their health records in real time, which is still not the case, despite government promises. This is a key pillar of The BMJ's patient and public partnership campaign (doi:10.1136/bmj.n1225). ${ }^{5}$ Such access is law in the US and elsewhere and should become law in the UK.

Trust is vital for healthcare workers struggling with the pandemic and its aftermath. Burnout among doctors and other healthcare workers was already a big problem before covid-19 but has vastly increased, made worse by staff shortages and failures in workforce planning (doi:10.1136/bmj.n1461). ${ }^{6} \mathrm{New}$ NHS guidance requiring wider provision of proper personal protective equipment

(doi:10.1136/bmj.n1422) ${ }^{7}$ should help morale, even while facial dermatoses ("maskne") continue to need proper care (doi:10.1136/bmj.n1304). ${ }^{8}$

Trust is bolstered by good information. Estimates of excess deaths, rather than reported covid-19 deaths, give a better measure of the pandemic's burden around the world (doi:10.1136/bmj.n1137). ${ }^{9}$ But deaths provide only a partial picture of the true impact, especially on younger people and those affected by long covid, say Jonathan Clarke and colleagues (doi:10.1136/bmj.n1239). ${ }^{10}$ Non-covid vaccination programmes have been badly hit (doi:10.1136/bmj.n1436), ${ }^{11}$ and global, gender, racial, and intergenerational inequalities are sure to increase unless urgently tackled.

The UK government's dire pandemic record doesn't make it the most obvious candidate to host this year's unprecedented G7 gathering. The UK has one of the world's worst death rates and the worst economic outcomes of any G7 country. These must be laid at the door of our leaders, whose disastrous decision making has been so floridly laid bare by Dominic Cummings

(https://blogs.bmj.com/bmj/2021/05/26/martin-mckee-what-did-we-learn-from-dominic-cummings-evidence-to-mps-on-the-covid-crisis), ${ }^{12}$ fuelling calls for an immediate public inquiry. The NHS vaccination programme is a single extraordinary ray of light, but it must not be allowed to cover for a national disaster (doi:10.1136/bmj.n1404). ${ }^{13}$

"A moment of national shame"

(https://blogs.bmj.com/bmj/2021/06/06/the-uk-mustnot-abandon-commitments-to-international-aidduring-a-global-pandemic) ${ }^{14}$ is more likely after the government's decision to break its own law and cut overseas development aid, with certain widespread loss of life and damage to global health security. Antimicrobial resistance will sadly be one winner from this decision, which, true to the government's pandemic record, pushes funding to a small set of technical and largely private sector solutions while undermining the global public health agenda (doi:10.1136/bmj.n1417). ${ }^{15}$ How long should we continue to place our trust in those who have shown themselves to be undeserving of it?

Salisbury H. Helen Salisbury: Should patients worry about their data?BMJ 2021;373:n1325. doi: 10.1136/bmi.n1325 pmid: 34035007

Seven days in medicine: 2-8 June 2021. BMJ 2021;373:a1455.

Salisbury H. Helen Salisbury: Should GPs break the law on data privacy?BMJ 2021;373:n1451doi: 10.1136/bmi.n1451.

4 Coulter A. Patient trust in plans to share primary care data. BMJ 2021;373:n1413. doi: 10.1136/bmi.n1413 pmid: 34088678

Richards T, Scowcroft H, Doble E, Price A, Abbasi K. Healthcare decision making should be democratised. BM/2021:373:n1225. doi: 10.1136/bmj.n1225 pmid: 34011490

6 lacobucci G. Staff burnout: MPs demand “total overhaul” of NHS workforce planning. BMJ2021;373:n1461doi: 10.1136/bmj.n1461

7 Torjesen I. Covid-19: PPE guidance is upgraded as evidence of airborne transmission grows. BMJ2021;373:n1422. doi: 10.1136/bmi.n1422 pmid: 34078639

8 Rudd E, Walsh S. Mask related acne ("maskne") and other facial dermatoses. BM/2021;373:n1304. doi: 10.1136/bmi.n1304 pmid: 34099456

9 Islam N, Shkolnikov VM, Acosta RJ, etal. Excess deaths associated with covid-19 pandemic in 2020: age and sex disaggregated time series analysis in 29 high income countries. BMJ2021;373:n1137. doi: 10.1136/bmi.n1137 pmid: 34011491

10 Clarke JM, Majeed A, Beaney T. Measuring the impact of covid-19. BMJ 2021;373:n1239. doi: 10.1136/bmi.n1239 pmid: 34011499

11 Mahase E. Childhood vaccination: Access problems in UK began way before covid-19. BMJ 2021;373:n1436doi: 10.1136/bmj.n1436.

12 McKee M. What did we learn from Dominic Cummings' evidence to MPs on the covid crisis? BMJ Opinion. 26 May 2021. https://blogs.bmj.com/bmj/2021/05/26/martin-mckee-what-did-we-learnfrom-dominic-cummings-evidence-to-mps-on-the-covid-crisis.

13 Abbasi K. Covid-19: Cummings, Johnson, Hancock, and a maelstrom of avoidable harm. BMJ2021:373:n1404 doi: 10.1136/bmj.n1404 pmid: 34074635

14 Rambhatla SB, Russell N, Eliasz MK, et al. The UK must not abandon commitments to international aid during a global pandemic. BMJ Opinion. 6 Jun 2021. https://blogs.bmj.com/bmj/2021/06/06/the-uk-must-notabandon-commitments-to-international-aid-during-a-global-pandemic.

15 Glover RE, Knight GM, Chandler CIR. Antimicrobial resistance at the G7. BMJ 2021;373:n1417. doi: 10.1136/bmi.n1417 pmid: 34083377

This article is made freely available for use in accordance with BMJ's website terms and conditions for the duration of the covid-19 pandemic or until otherwise determined by BMJ. You may use, download and print the article for any lawful, non-commercial purpose (including text and data mining) provided that all copyright notices and trade marks are retained. 